\title{
Unsere Männer
}

Sie sind ja schon etwas Besonderes - unsere Männer. Allein deswegen, weil man in der Ergowelt lange nach ihnen suchen muss. Oder haben Sie jemals geschlechtlich ausgewogene Schulklassen, Fortbildungsgruppen oder Kongressbesucher in der Ergotherapie gesehen? Umso mehr wundert es mich, dass ich meinen Beruf überhaupt erst durch einen männlichen Ergotherapeuten ergriffen habe. Nach dem Abi machte ich ein Schnupperpraktikum in seiner Praxis (ich wusste partout nicht, was ich einmal werden möchte). Für diese menschliche, lehrreiche und augenöffnende Zeit bin ich ihm heute noch dankbar. Während meiner Praxiszeit hatte ich leider nie männliche Kollegen. Darum schätze ich den inspirierenden Austausch mit innen in der Arbeitsgruppe, der ich heute angehöre, umso mehr - ich finde, die Mischung macht's.

Aber woran liegt es, dass so wenige Männer unseren Beruf ergreifen? Diese Frage hat sich auch ein Ergotherapiestudent der

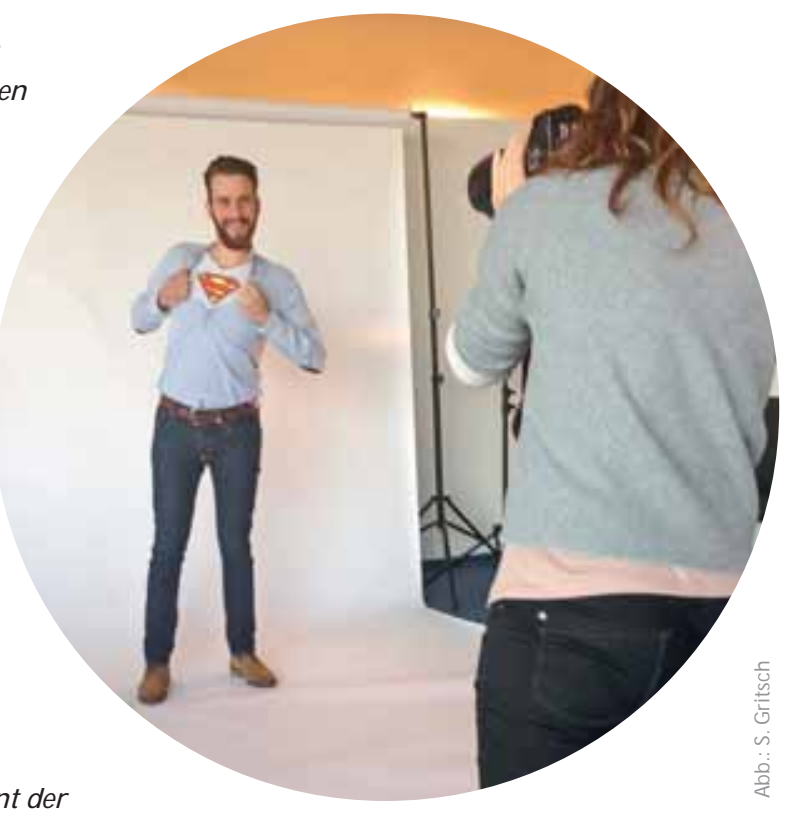
Hochschule Fresenius gestellt und zum Thema seiner Bachelorarbeit gemacht. Die Antworten, die er gefunden hat, und wie es Männern unter all den Frauen ergeht, lesen Sie ab Seite 38.

Beim Thema „Männer in der Ergotherapie" sind in der Redaktion die Geschichten nur so gesprudelt. Zugegeben, auch wir wussten ganz klischeemäßig von den „weichen“ Ergo-Männern auf der einen Seite und den knallharten „Machern“ auf der anderen zu erzählen. Schnell war klar: Das wird unser Titelthema! Beim Fotoshooting hatten wir jede Menge Spaß und hoffen, dass ihr, liebe Kollegen, mit uns zusammen über das Ergebnis schmunzeln könnt. Denn euch sei diese Ausgabe gewidmet - was wären wir nur ohne euch!

Herzlichst

Ihre

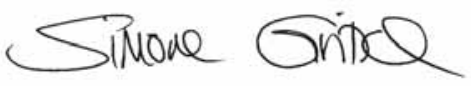

